\title{
Exposure to particulate matter in a mosque
}

\author{
Yılmaz Ocak ${ }^{a}$, Akın Kılıçvuran ${ }^{a}$, Aykut Balkan Eren ${ }^{a}$, Aysun Sofuoglu ${ }^{\text {a,b }}$, Sait C. Sofuoglu ${ }^{\text {a,b,* }}$ \\ a İmir Institute of Technology, Department of Chemical Engineering, Gülbahçe, Urla 35430 İzmir, Turkey \\ b Izmir Institute of Technology, Environmental Research Center, Gülbahçe, Urla 35430 İzmir, Turkey
}

\section{A R T I C L E I N F O}

\section{Article history:}

Received 1 December 2011

Received in revised form

19 March 2012

Accepted 2 April 2012

\section{Keywords:}

Indoor air quality

Mosque

Particulate matter

Cleaning

Human activity

\begin{abstract}
A B S T R A C T
Indoor air quality in mosques during prayers may be of concern for sensitive/susceptible sub-groups of the population. However, no indoor air pollutant levels of potentially toxic agents in mosques have been reported in the literature. This study measured PM concentrations in a mosque on Friday when the mid-day prayer always receives high attendance. Particle number and $\mathrm{CO}_{2}$ concentrations were measured on nine sampling days in three different campaigns before, during, and after prayer under three different cleaning schedules: vacuuming a week before, a day before, and on the morning of the prayer. In addition, daily $\mathrm{PM}_{2.5}$ concentrations were measured. Number concentrations in $0.5-1.0$, 1.0-5.0, and $>5.0 \mu \mathrm{m}$ diameter size ranges were monitored. In all campaigns the maximum number concentrations were observed on the most crowded days. The lowest number concentrations occurred when vacuuming was performed a day before the prayer day in two of the three size ranges considered. $\mathrm{PM}_{2.5}$ concentrations (four-hour samples that integrated before, during, and after the prayer) were comparable to the other indoor environments reported in the literature. $\mathrm{CO}_{2}$ concentrations suggested that ventilation was not sufficient in the mosque during the prayers. The results showed that better ventilation, a preventive cleaning strategy, and a more detailed study are needed.
\end{abstract}

(C) 2012 Elsevier Ltd. All rights reserved.

\section{Introduction}

Particulate matter (PM) can be categorized into three size ranges as ultrafine $\left(d_{\mathrm{p}}<0.1 \mu \mathrm{m}\right.$, UFP), fine $\left(0.1<d_{\mathrm{p}}<2.5 \mu \mathrm{m}\right)$, and coarse $\left(d_{\mathrm{p}}>2.5 \mu \mathrm{m}\right)$ particles (Hinds, 1999). However, due to their potential for human health effects the coarse PM size range is generally restricted to $2.5<d_{\mathrm{p}}<10 \mu \mathrm{m}$. Numerous studies reported adverse health effects of all three sizes of PM (Loomis, 2000; Pope, 2000; Hauser et al., 2001; Pope and Dockery, 2006). PM may be responsible for producing or exacerbating pulmonary inflammation (Ghio et al., 2000) and asthma in children and elderly (Pekkanen et al., 1997; Andersen et al., 2008).

Although the main source of PM is thought to be the outdoor air, there are many secondary indoor sources that involve human activities such as walking, sitting, dusting, vacuuming that result in the resuspension of dust (Thatcher and Layton, 1995; Abt et al., 2000a; Fromme et al., 2008; Stranger et al., 2008; Branis et al., 2009). Human activities, especially vacuuming have been reported to increase the concentrations 1.2 times to 29.5 times depending on the particle size (Thatcher and Layton, 1995; Corsi et al., 2008;

\footnotetext{
* Corresponding author. İzmir Institute of Technology, Department of Chemical Engineering, Gülbahçe, Urla 35430 İzmir, Turkey. Tel.: +90 232750 6648; fax: +90 2327506645.

E-mail addresses: cemilsofuoglu@iyte.edu.tr, saitcemil@iit.edu (S.C. Sofuoglu).
}

Qian et al., 2008). Overall 46-93\% (25 and 75 percentile values, respectively) of the $\mathrm{PM}_{2.5}$ was found to originate from the outdoors with a median value of 56\% (Meng et al., 2005).

All around the world mosques are places of worship where the floor is carpeted wall-to-wall and entrance with shoes is prohibited. Mosques often become fully occupied raising the occupant density to $>1.5$ persons $/ \mathrm{m}^{2}$ during worship hours. Carpets are a sink for $\mathrm{PM}$ when there is no prayer and a source during the prayers due to resuspension as a result of occupant movements. However, shoeless entrance would reduce transport of particles from outdoors to indoors, and carpet vacuuming is performed regularly, usually two to four times per month, which should minimize the amount of particles available for resuspension. Nevertheless PM exposure during prayers may be a health concern for sensitive population subgroups such as people with respiratory diseases and elderly.

Indoor air quality (IAQ) in mosques has not been a subject of prior investigations. Only occupant comfort issues were studied (Al-Homoud et al., 2009; Al-Ajmi, 2010). IAQ in places of worship was a subject of investigations for temples in Asia (Fang et al., 2002; Wang et al., 2007) and churches (de Santis et al., 1996; de Kok et al., 2004; Weber, 2006; Loupa et al., 2010) mainly due to incense burning. Weber (2006) measured particle number concentrations for $0.3<d_{\mathrm{p}}<32 \mu \mathrm{m}$, which then were converted to $\mathrm{PM}_{10}, \mathrm{PM}_{2.5}$, and $\mathrm{PM}_{1}$ concentrations, during service with and without incense burning. Average particle mass concentrations during conventional 
(without insence burning) service ( $13 \mu \mathrm{g} \mathrm{m}^{-3}$ for $\mathrm{PM}_{1}, 16 \mu \mathrm{g} \mathrm{m}^{-3}$ for $\mathrm{PM}_{2.5}$, and $19 \mu \mathrm{g} \mathrm{m}^{-3}$ for $\mathrm{PM}_{10}$ ), were about 1.5 times the background concentrations. During conventional service the average number concentrations were $1900 \mathrm{~cm}^{-3}$ for $0.3-1 \mu \mathrm{m}$ and $<10 \mathrm{~cm}^{-3}$ for $>1 \mu \mathrm{m}$ particle size ranges. These concentrations were about 1.7 times the background concentrations for $d_{\mathrm{p}}<2 \mu \mathrm{m}$. The ratio increased for larger particles reaching up to $\sim 10$ times the background for $7-8 \mu \mathrm{m}$, and $\sim 12$ for $10 \mu \mathrm{m}$. Because this increase in the ratio was also observed during service with incense burning, the increase in $d_{\mathrm{p}}>2 \mu \mathrm{m}$ particles were attributed to resuspension of deposited particle by the movements of worshippers. Loupa et al. (2010) measured particle number concentrations of eight size ranges in two medieval churches while different activities were occurring. The presence/movements of worshippers increased concentrations for $d_{\mathrm{p}}>1 \mu \mathrm{m}$, whereas sweeping the floors significantly increased $\mathrm{PM}_{2-10}$ concentrations (up to five times) and slightly increased $\mathrm{PM}_{0.3-2}$ concentrations. Estimated 24-h $\mathrm{PM}_{0.3-2}$ mass concentrations $\left(25-35 \mu \mathrm{g} \mathrm{m}^{-3}\right.$ ) were in excess of the WHO $\mathrm{PM}_{2.5}$ limit value of $25 \mu \mathrm{g} \mathrm{m}^{-3}$.

The aim of this study was to investigate particle number, mass $\left(\mathrm{PM}_{2.5}\right)$, and $\mathrm{CO}_{2}$ concentrations in a rural mosque located away from major sources before, during, and after prayer as a function of cleaning schedule and occupancy.

\section{Materials and methods}

\subsection{Sampling location}

Sampling was conducted in a relatively small mosque in Gulbahce, a village about $45 \mathrm{~km}$ from Izmir, Turkey, close by to the Izmir Institute of Technology campus. The indoor volume of the mosque is $735 \mathrm{~m}^{3}$ (length $15 \mathrm{~m} \times$ width $7 \mathrm{~m} \times$ height $7 \mathrm{~m}$ ). In addition to the ground floor with a capacity of about 140 people, it has a mezzanine floor (about 30 people capacity). Two indoor split AC units were present for heating and cooling purposes (100\% recycled indoor air).

\subsection{Sampling}

Although prayers are held five times a day, Friday prayer which is held at noon on Fridays was selected for sampling because attendance is high and generally the mosque is fully occupied. This study was designed to observe the effect of (1) cleaning time, and (2) number of occupants on particle number concentrations by including three consecutive sampling periods each sampling day: before, during, and after the prayer. The carpeting, made of natural fibers, was vacuumed on three time schedules: a week before the prayer day, a day before the prayer day, and on the morning of the prayer day. There were nine sampling days in consecutive threeweek groups conducted in (1) April 2010, (2) December 2010, and (3) December 2010-January 2011. Windows were closed during all sampling days. Campaign-2 $\mathrm{CO}_{2}$ data were lost due to the failure of the data logger following a power outage. In addition, due to the power outage the $\mathrm{PM}_{2.5}$ concentration of Day-3 in Campaign- 2 could not be determined. Furthermore, particle number concentrations in that day are not available for about the 2nd half of the monitoring period. The air conditioners were only used for heating during the last two days of the third campaign. Information regarding the sampling are summarized in Table 1.

Sampling and measurement instruments were placed on the center of the mezzanine floor at the closest point to the center of the ground floor. Detectors and sampling inlets were hung down to $2.5 \mathrm{~m}$ above the center point of the ground floor so they would not impact the worshippers when standing.
Table 1

Sampling summary information.

\begin{tabular}{|c|c|c|c|c|c|c|c|c|c|}
\hline & \multicolumn{3}{|c|}{ Campaign-1 } & \multicolumn{3}{|c|}{ Campaign-2 } & \multicolumn{3}{|c|}{ Campaign-3 } \\
\hline & Day-1 & Day-2 & Day-3 & Day-1 & Day-2 & Day-3 & Day-1 & Day-2 & Day-3 \\
\hline \multirow[t]{2}{*}{ Date } & $04 / 02$ & $04 / 09$ & $04 / 16$ & $12 / 03$ & $12 / 10$ & $12 / 17$ & $12 / 24$ & $01 / 07$ & $01 / 21$ \\
\hline & 2010 & 2010 & 2010 & 2010 & 2010 & 2010 & 2010 & 2011 & 2011 \\
\hline Cleaning $^{\mathrm{a}}$ & W & $\mathrm{D}$ & M & M & W & $\mathrm{D}$ & M & M & $\mathrm{M}$ \\
\hline Attendance & 115 & 120 & 150 & 168 & 156 & 140 & 160 & 172 & 156 \\
\hline AC Use & No & No & No & No & No & No & No & Yes & Yes \\
\hline
\end{tabular}

a $\mathrm{W}$ : a week before, $\mathrm{D}$ : a day before, M: on the morning of the prayer day.

\subsection{Instruments}

A laser optical airborne particle counter (CliMet CI-450) with a flow rate of $50 \mathrm{~L} \mathrm{~min}^{-1}$ was used to collect 1-min air samples every three minutes to measure particle number concentrations in three size ranges: $0.5-1.0 \mu \mathrm{m}\left(\mathrm{PM}_{0.5-1.0}\right), 1.0-5.0 \mu \mathrm{m}\left(\mathrm{PM}_{1.0-5.0}\right)$, and $>5.0 \mu \mathrm{m}\left(\mathrm{PM}_{>5} .0\right)$. Measured concentrations were stored in a builtin data logger and later transferred to a computer for analysis.

$\mathrm{PM}_{2.5}$ samples were collected using an air sampling pump connected to a Harvard impactor (SP 280E, Air Diagnostics and Engineering Inc.) with a $20 \mathrm{~L} \mathrm{~min}^{-1}$ flow rate for four hours on 37-mm glass-fiber filters (Pall, Type A/E, pores $1 \mu \mathrm{m}$ ). Due to concern about collecting a sufficient amount of particles for weighing, only one sample was collected per day. The flow rate of the sampling unit was calibrated (Defender 510, Bios International Corp.) before each sample, and measured at the end of the sampling period. The average (and standard deviation) percent difference from the set flow rate was $1.4 \%$ (1.1).

In the weighing laboratory the filters were placed in a desiccator $24 \mathrm{~h}$ prior to weighing. A precision-balance with a $10 \mu \mathrm{g}$-resolution (Sartorius CPA 225D) was used. The minimum difference between before and after sampling filter weights was $130 \mu \mathrm{g}$, which was 13 times the resolution of the balance. The average (and standard deviation) difference between before and after weights of field blanks $(n=9)$ was $10.7(2.8) \mu \mathrm{g}$. The mean of the standard deviation of triplicate readings of the nine samples was $10.9 \mu \mathrm{g}$. The error in measured $\mathrm{PM}_{2.5}$ concentrations were estimated by error propagation using uncertainties in the flow rate and weighting. $\mathrm{CO}_{2}$ concentrations were monitored using a hand-held monitor (Testo 400 ) on the same scheduling as particle number concentrations.

\section{Results and discussion}

\section{1. $\mathrm{CO}_{2}$ concentrations}

Carbon dioxide concentrations are a good indicator of ventilation in crowded environments. In this study, $\mathrm{CO}_{2}$ concentration levels were measured in Campaign-1 and -3. Overall, the before concentration levels were similar for the six sampling days (Fig. 1). The concentrations were increased during the prayer, peaking at the end of the prayer. The highest concentrations were measured as 2850 ppm in Campaign-1 (Fig. 1a) and as 2560 ppm in Campaign-3 (Fig. 1b). $\mathrm{CO}_{2}$ concentrations started to decrease with people leaving at the end of the prayer. Higher concentrations were observed on higher attendance days. $\mathrm{CO}_{2}$ concentrations during the prayers were $>700 \mathrm{ppm}$ above the outdoor air levels $(350 \pm 20$ ppm average \pm standard deviation, measured close by at Izmir Institute of Technology campus [Durmus Arsan, 2012]) indicating ventilation was not sufficient (ASHRAE, 2001).

A considerably shifted $\mathrm{CO}_{2}$ concentration profile was observed in the 3rd day of Campaign-3 (Fig. 1b) which may be attributed to the operation of the ACs for heating as it improved mixing into the higher portions of the $7 \mathrm{~m}$ high-volume. However a shift was not 


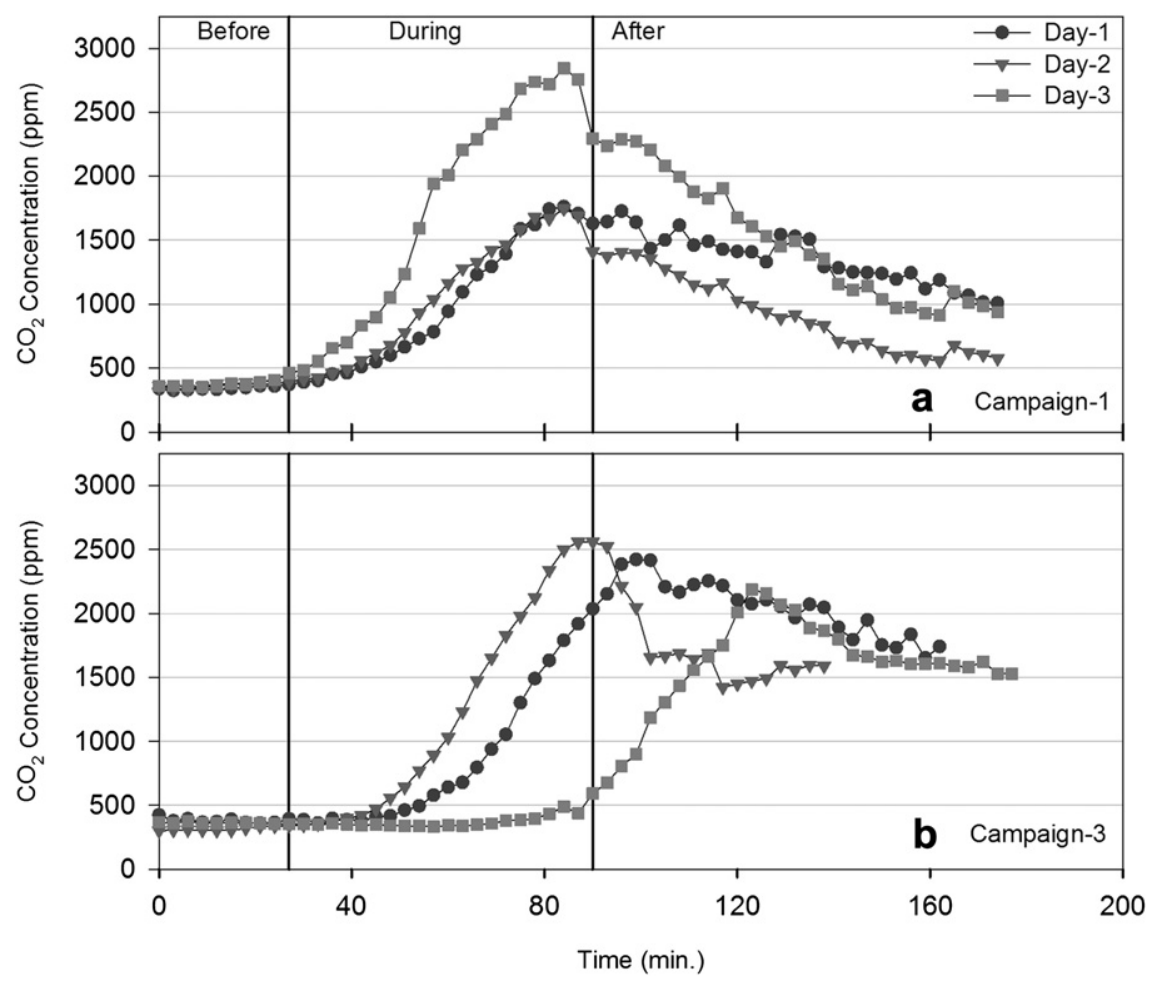

Fig. 1. $\mathrm{CO}_{2}$ concentrations before, during, and after prayer in (a) Campaign-1 and (b) Campaign-3.

observed on Day-2 of Campaign-3 although AC was also in use. The effect of running the AC units is also discussed with the particle number concentrations (see Section 3.3).

A t-test was used to compare the mean $\mathrm{CO}_{2}$ concentrations between campaigns ( $p$-values are presented in Table 2). Significant differences at $\alpha=0.001$ were found except for Day- 1 vs. Day- 2 in both Campaign-1 and -3. If the AC use is controlled for (considering only No-No situations; Yes-Yes situation was not considered because of the difference in concentration profiles on those two days) a difference of 25 in attendance is sufficient for a statistically significant increase in the $\mathrm{CO}_{2}$ concentrations (Day-1 vs. Day-3, $251 \mathrm{ppm}$, Table 2).

\section{2. $P M_{2.5}$ mass concentrations}

The World Health Organization (WHO) has a short-term (24-hour) guideline value of $25 \mu \mathrm{g} \mathrm{m}^{-3}$ for $\mathrm{PM}_{2.5}$ (WHO, 2006) while USEPA's 24-h standard is listed as $35 \mu \mathrm{g} \mathrm{m}^{-3}$ for ambient air (USEPA, 2006). Canadian indoor exposure guidelines recommend $100 \mu \mathrm{g} \mathrm{m}^{-3}$ as acceptable short-term (1-h) exposure (Health-Canada, 1987). In this study some of the measured $\mathrm{PM}_{2.5}$ concentrations, which were based on 4-h sampling, were higher than the 24-h WHO guideline and USEPA standard concentrations; whereas all except one were lower than the 1-h guideline (Table 3). The measured concentrations in the mosque were higher than the concentrations measured in churches during conventional services, but they were lower than those measured during services with incense burning (Weber, 2006; Loupa et al., 2010). Some of the concentrations measured in this study were at comparable levels to those measured in schools where they are elevated primarily due to resuspension of deposited particles as the result of intense movements of the children. Up to $72 \mu \mathrm{g} \mathrm{m}^{-3} \mathrm{PM}_{2.5}$ concentrations were measured in schools of other countries (Ward and Noonan, 2007; Crist et al., 2008; Branis et al., 2009) whereas up to $95 \mu \mathrm{g} \mathrm{m}{ }^{-3}$ were measured in Istanbul, Turkey (Ekmekcioglu and Keskin, 2007).

\subsection{Particle number concentrations}

Particle number concentration levels were measured in every three minutes in three size ranges: $0.5-1.0 \mu \mathrm{m}\left(\mathrm{PM}_{0.5-1.0}\right)$, 1.0-5.0 $\mu \mathrm{m}\left(\mathrm{PM}_{1.0-5.0}\right)$, and $>5.0 \mu \mathrm{m} \quad\left(\mathrm{PM}_{>5.0}\right)$. The measured concentrations before, during and after the prayer and are given in Figs. 2-4 for the three sampling campaigns, respectively. The variation in $\mathrm{PM}_{0.5-1.0}$ concentrations can be seen in Figs. 2a, 3a, and 4a. Particles of this size range do not vary considerably due to people coming in and going out the mosque, and movements during prayer compared to the two larger size range particles. There are some fluctuations however those appear to be inconsistent as no

Table 2

Comparison of the mean $\mathrm{CO}_{2}$ concentrations.

\begin{tabular}{|c|c|c|c|c|c|c|}
\hline & \multicolumn{3}{|l|}{ Campaign-1 } & \multicolumn{3}{|l|}{ Campaign-3 } \\
\hline & Day-1/Day-2 & Day-1/Day-3 & Day-2/Day-3 & Day-1/Day-2 & Day-1/Day-3 & Day-2/Day-3 \\
\hline Mean & $876 / 737$ & $876 / 1127$ & $737 / 1127$ & $1217 / 1212$ & $1217 / 789$ & $1212 / 789$ \\
\hline Standard Dev. & $526 / 437$ & $526 / 805$ & $437 / 805$ & $821 / 766$ & $821 / 650$ & $766 / 650$ \\
\hline$p$-Value & 0.07 & $<0.001$ & $<0.001$ & 0.93 & $<0.001$ & $<0.001$ \\
\hline Attendance & $115-120$ & $125-150$ & $115-150$ & $160-172$ & $160-156$ & $172-156$ \\
\hline AC use & No-No & No-No & No-No & No-Yes & No-Yes & Yes-Yes \\
\hline
\end{tabular}


Table 3

$\mathrm{PM}_{2.5}$ concentrations in the mosque.

\begin{tabular}{|c|c|c|c|c|c|c|c|c|c|}
\hline & \multicolumn{3}{|c|}{ Campaign-1 } & \multicolumn{3}{|c|}{ Campaign-2 } & \multicolumn{3}{|c|}{ Campaign-3 } \\
\hline & Day-1 & Day-2 & Day-3 & Day-1 & Day-2 & Day-3 & Day-1 & Day-2 & Day-3 \\
\hline $\mathrm{PM}_{2.5}\left(\mu \mathrm{g} \mathrm{m}^{-3}\right)^{\mathrm{a}}$ & $\begin{array}{l}29 \\
(0.5)\end{array}$ & $\begin{array}{l}38 \\
(0.6)\end{array}$ & $\begin{array}{l}52 \\
(0.9)\end{array}$ & $\begin{array}{l}23 \\
(0.4)\end{array}$ & $\begin{array}{l}122 \\
(2.1)\end{array}$ & $N A^{b}$ & $\begin{array}{l}56 \\
(1.0)\end{array}$ & $\begin{array}{l}22 \\
(0.4)\end{array}$ & $\begin{array}{l}14 \\
(0.2)\end{array}$ \\
\hline
\end{tabular}

a Numbers in parentheses are propagated error.

b Not available due to power outage.

similarities were observed among the three campaigns. Concentrations of particles in the two larger size ranges $\left(\mathrm{PM}_{1.0-5.0}\right.$ and $\left.\mathrm{PM}_{>5.0}\right)$ showed a similar behavior in that they increased with people coming in and praying, and decreased with people leaving the building. However the concentrations did not decrease back to background levels at the end of the monitoring period (see Figs. 2-4) except for Day-2 of Campaign-1.

The concentrations increased 3 to 8 -folds during the prayers over the concentrations before the prayers, which indicate that resuspension from the carpeted surface may play an important role in human exposure to particles $>1 \mu \mathrm{m}$ in diameter. PM concentration increase during service were attributed to presence and movement of worshippers in churches by Weber (2006) for $d_{\mathrm{p}}>2 \mu \mathrm{m}$ (an increase of approximately two times for $d_{\mathrm{p}}=2 \mu \mathrm{m}$, five times for $d_{\mathrm{p}}=5 \mu \mathrm{m}$, ten times for $d_{\mathrm{p}}=7-8 \mu \mathrm{m}$, and 12 times for $d_{\mathrm{p}}=10 \mu \mathrm{m}$ compared to background levels). The ratio of PM concentrations measured during occupancy to non-occupancy periods in a university classroom increased with particle size (1.35 for $\mathrm{PM}_{0.3-0.4}, 4.58$ for $\mathrm{PM}_{2.0-3.0}, 12.44$ for $\mathrm{PM}_{5.0-7.5}, 68.70$ for $\mathrm{PM}_{15-20}$ ). The increase in the mean concentrations was associated with students walking in and out at the beginning and the end of the lectures (Alshitawi and Awbi, 2011). Loupa et al. (2010) related increases in indoor concentrations in a church for $d_{\mathrm{p}}>1 \mu \mathrm{m}$ compared to outdoor levels to the presence of visitors or cleaning activity. Data collected in residences showed that concentration increases in $d_{\mathrm{p}}>1-2 \mu \mathrm{m}$ were associated with cooking, cleaning, and movement of people (Abt et al., 2000b). The estimated source emission rates for all the three occupant activities were similar for $\mathrm{PM}_{0.7-10}$.

Vacuuming is known to be strong source of particles in the size range of $1-10 \mu \mathrm{m}$ (Abt et al., 2000b; Long et al., 2000); stronger than many human activities for $\mathrm{PM}_{2.5}$ (Ferro et al., 2004). Qian et al.

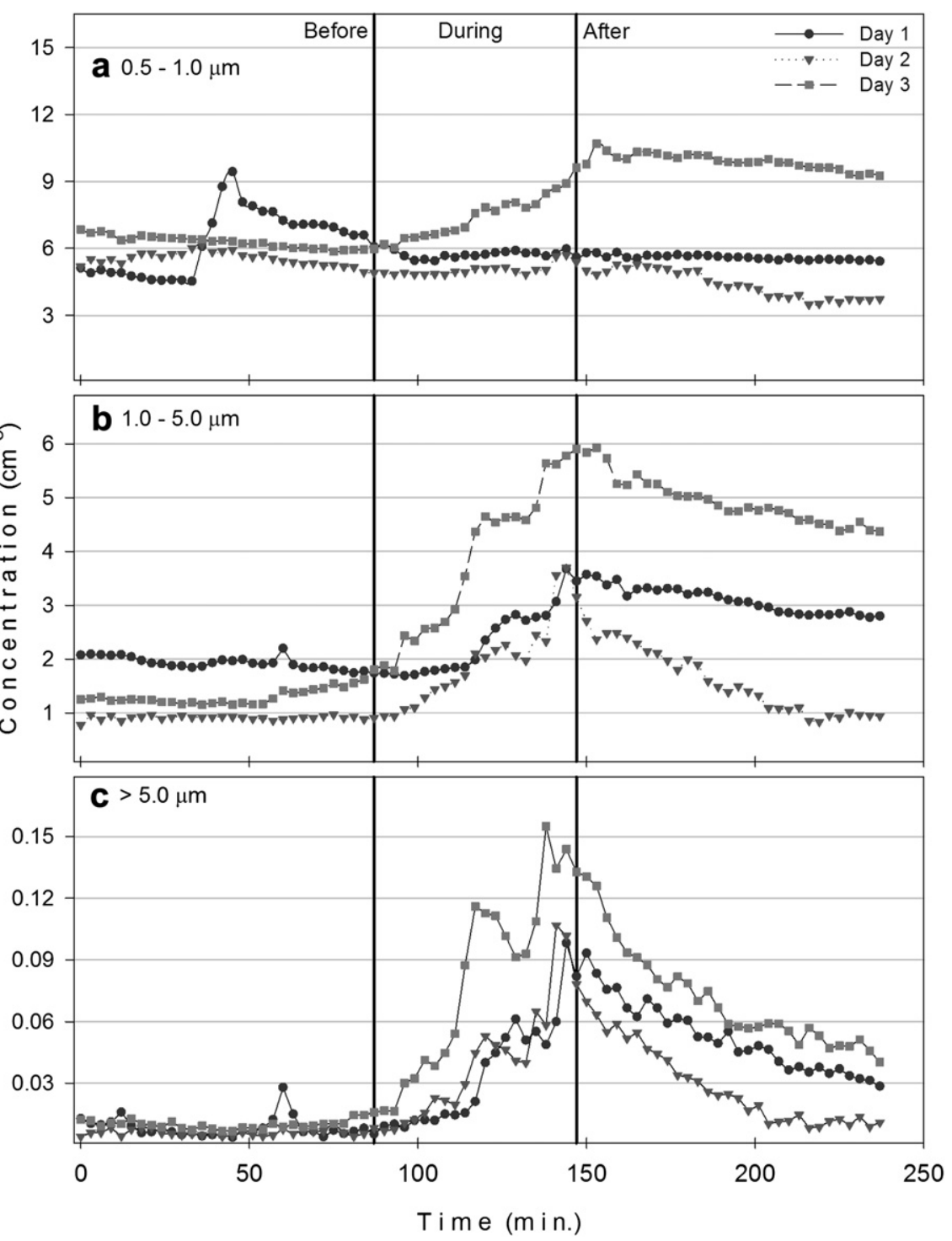

Fig. 2. Variation in (a) $\mathrm{PM}_{0.5-1.0}$, (b) $\mathrm{PM}_{1.0-5.0}$, (c) $\mathrm{PM}_{>5}$ concentrations before, during and after prayer for Campaign-1. 


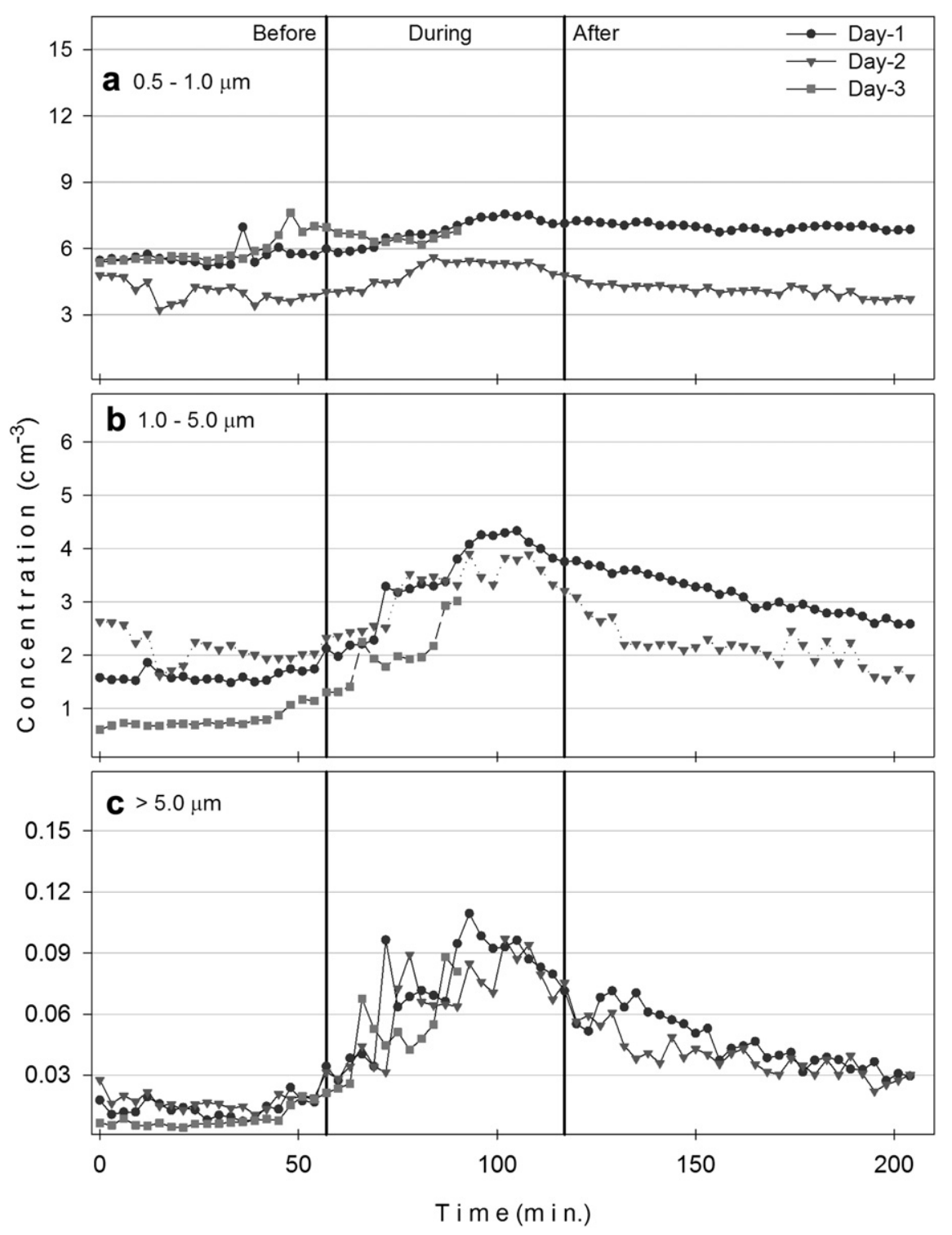

Fig. 3. Variation in (a) $\mathrm{PM}_{0.5-1.0}$, (b) $\mathrm{PM}_{1.0-5.0}$, (c) $\mathrm{PM}_{>5}$ concentrations before, during and after prayer for Campaign-2.

(2008) estimated that resuspension by human activity (walking, sitting on furniture, vacuuming) elevate indoor $\mathrm{PM}_{10}$ concentration 2.5 times on average and 4.5 times at peak concentration, compared to the background levels. The average increase in $\mathrm{PM}_{10}$ reached up to four times in vacuuming experiments with one type of vacuum cleaner by Corsi et al. (2008) whom estimated that approximately half the mass emitted was caused by the action of walking on the carpet. During vacuuming the increase reached up to 29.5 times for $10-25 \mu \mathrm{m}$ particles while it was only 1.2 times for 0.5-1 $\mu \mathrm{m}$ particles (Thatcher and Layton, 1995).

However, vacuuming is also reported to be an effective tool to decrease the floor loading, and to shorten the overall indoor air residence time of a particulate pollutant (Qian et al., 2008). In this study three vacuuming schedules were examined: a week before the prayer day, a day before the prayer day, and in the morning of the prayer day. The background concentrations were to be the average of the first five measurements of each day (see Table 4). It was assumed that the difference in these background concentrations were mainly due to the difference in the vacuuming schedule among other factors, most importantly outdoor concentrations (infiltration) which were not measured. Campaign-3 was not included since the priest preferred to have the cleaning on the morning of the prayer day, opting not to adhere to our original sampling plan. The average of the first five measurements for $\mathrm{PM}_{0.5-1.0}$ was the highest when vacuuming was done on the morning of the prayer day, whereas it was the highest for both of the upper two size ranges $\left(\mathrm{PM}_{1.0-5.0}\right.$ and $\left.\mathrm{PM}_{>5.0}\right)$ when vacuuming was performed a week before the prayer day. This finding suggests that vacuuming a day before the prayer day produced the lowest particle number levels for two of the three size ranges considered. When all measured concentrations were considered, instead of just the first five, the mean values of the intra-campaign concentrations can be compared with each other using a t-test. The differences were statistically significant ( $p$-values $<0.05$ ), which indicates that attendance and the cleaning schedule or additional variables that we could not include in the study such as infiltration, meteorological variables, etc. have an effect on indoor air the number concentrations.

In Campaign-3, vacuuming was performed on the morning of the sampling day for all three sampling days, because it was the 


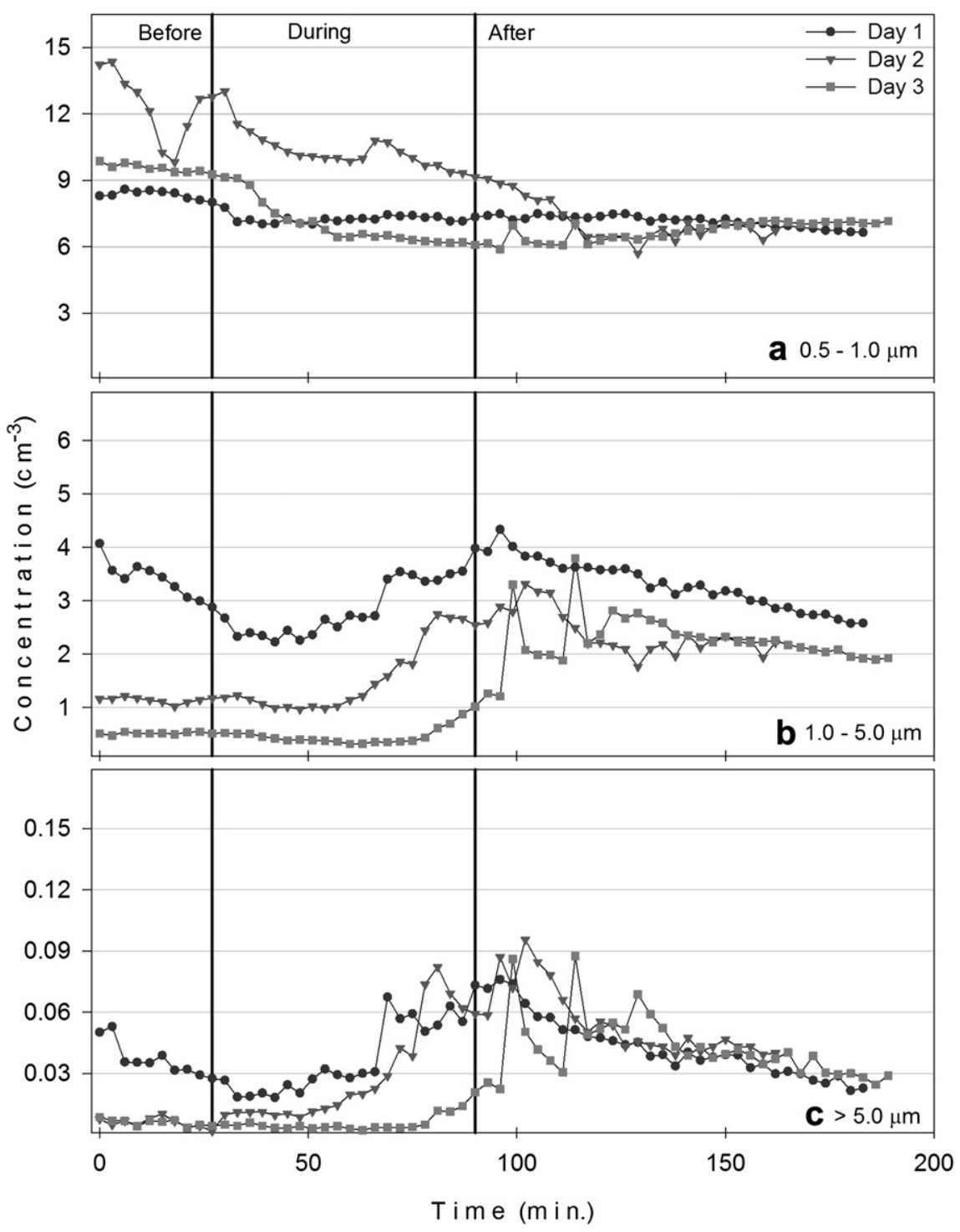

Fig. 4. Variation in (a) $\mathrm{PM}_{0.5-1.0}$, (b) $\mathrm{PM}_{1.0-5.0}$, (c) $\mathrm{PM}_{>5}$ concentrations before, during and after prayer for Campaign-3.

preference of the priest. Different from other sampling days, air conditioners (ACs) were used for heating on the last two days (Day2 and Day-3). The ACs are 100\% recycle floor standing split units placed on the corners of the long side of the floor facing in at a $60^{\circ}$ angle. Air conditioning units would result in higher air velocities and better mixing of the indoor air. Heated air blown at high speeds horizontally out of the AC units at a height of $1.5-1.7 \mathrm{~m}$ would first

Table 4

Average (and Standard Deviation) of the first five particle number concentrations $\left(\mathrm{cm}^{-3}\right)$ and cleaning schedule.

\begin{tabular}{llllll}
\hline & & Cleaning $^{\mathrm{a}}$ & \multicolumn{3}{l}{ Particle size range $(\mu \mathrm{m})$} \\
\cline { 3 - 6 } & & & $0.5-1.0$ & $1.0-5.0$ & $>5.0$ \\
\hline Campaign-1 & Day1 & $\mathrm{W}$ & $4.97(0.10)$ & $2.08(0.01)$ & $0.120(0.002)$ \\
& Day2 & $\mathrm{D}$ & $5.39(0.14)$ & $0.89(0.08)$ & $0.006(0.002)$ \\
& Day3 & $\mathrm{M}$ & $6.67(0.18)$ & $1.26(0.03)$ & $0.011(0.001)$ \\
Campaign-2 & Day1 & $\mathrm{M}$ & $5.57(0.11)$ & $1.61(0.14)$ & $0.014(0.004)$ \\
& Day2 & W & $4.58(0.27)$ & $2.49(0.17)$ & $0.021(0.005)$ \\
& Day3 & $\mathrm{D}$ & $5.46(0.06)$ & $0.68(0.05)$ & $0.006(0.001)$ \\
\hline
\end{tabular}

a $\mathrm{W}$ : a week before, $\mathrm{D}$ : a day before, M: on the morning of the prayer day. mix with surrounding air and then rise, dispersing the particles into the upper parts of the volume above human height. Therefore, lower concentrations could be expected due to better dispersion (considering the samples were drawn at the center of the floor at a height of $2.5 \mathrm{~m}$ ) compared to days with no heating, resulting in a delay of the concentration increase onset. The two larger size range $\left(\mathrm{PM}_{1.0-5.0}\right.$ and $\left.\mathrm{PM}_{>5}\right)$ number concentrations were clearly lower on the two AC days than the first sampling day, especially during the prayers, even though attendances were comparable. The difference was about two times for $\mathrm{PM}_{1.0-5.0}$ and 1.35 times for $\mathrm{PM}_{>5}$ overall, while it was about four times during the prayer for both of the size ranges.

Particle number concentrations measured in two churches (Loupa et al., 2010) remained under $300 \mathrm{~cm}^{-3}$ and $0.4 \mathrm{~cm}^{-3}$ for $0.3-2 \mu \mathrm{m}$ and $2-10 \mu \mathrm{m}$ size ranges, respectively, unless candles were burnt during services. Average concentrations of $\mathrm{PM}_{0.3-1}$ measured in a church were $11,000 \mathrm{~cm}^{-3}$ and $1900 \mathrm{~cm}^{-3}$ during services with and without incense burning, respectively (Weber, 2006). The corresponding concentrations for $\mathrm{PM}_{>1}$ were $<100$ and $<10 \mathrm{~cm}^{-3}$, respectively. The concentrations during services were higher than the background concentrations, about two orders of magnitude 
higher during incense burning services, and about two-folds higher during conventional services (Weber, 2006). The conclusion was that incense burning was the main human activity that gave rise to submicron particles, while the presence and movements of worshippers increased super-micron particle concentrations.

Tippayawong and coworkers (2009) reported particle number concentrations in a school. The highest concentrations were measured for particles in the $0.3-0.5 \mu \mathrm{m}$ size range with an average value of $180 \mathrm{~cm}^{-3}$ while the lowest concentrations were measured in the $2.5-5 \mu \mathrm{m}$ size range with an average of $0.05 \mathrm{~cm}^{-3}$. Parker and coworkers (2008) reported that while the smallest particle $(0.3-0.4 \mu \mathrm{m})$ concentrations remained relatively constant over a day between about 4 and $8 \mathrm{~cm}^{-3}$, coarse particles $(7.5-10 \mu \mathrm{m})$ rose with occupancy from zero to about $0.025 \mathrm{~cm}^{-3}$ during typical days. The indoor concentrations were increased up to four folds in the smaller size range during a five-day ambient air pollution episode, whereas the increase in the larger size range was only 1.5 folds showing the effect of penetration from ambient air to indoor air in a mechanically ventilated building. The building studied by Tippayawong et al. (2009) was naturally ventilated and had higher concentrations than those measured in this study, while Parker et al. (2008) studied a mechanically ventilated building which had lower concentrations. In this study, the building was naturally ventilated and the windows were kept closed at all times, however the entrance door was kept open which may have served as a route for PM transport from outside. The levels measured in this study in a mosque are similar to those measured in the schools, but somewhat lower than those measured in the churches.

\section{Conclusions}

$\mathrm{CO}_{2}$ and particle number concentrations were measured in the mosque before, during, and after Friday prayer in three different cleaning schedules: vacuuming a week before, a day before, and on the day of the prayer. The $\mathrm{PM}_{2.5}$ concentration was also measured for each prayer day. The $\mathrm{CO}_{2}$ concentration profiles showed that ventilation was not sufficient during the prayer. $\mathrm{PM}_{2.5}$ mass concentrations were lower than a 1-h exposure guideline value indicating that no adverse effects should be anticipated on healthy worshippers. The highest particle number concentrations were observed on the most crowded days of each campaign. The number concentration variations were more pronounced for particles in the largest size range, which may indicate that resuspension from a carpeted surface has an important role in human exposure to coarse particles in mosques. The lowest number concentrations occurred when vacuuming was performed a day before the prayer day. Keeping this vacuuming schedule and promoting mixing in the volume would help to protect sensitive/susceptible worshippers from potential effects of PM.

\section{Conflict of interest}

The authors declare that there are no conflicts of interest.

\section{Acknowledgements}

Geothermal Energy Research and Application Center and Building Physics Research Laboratories of School of Architecture at Izmir Institute of Technology, and TUBITAK (Grant No. 105Y263) are acknowledged for the particle counter, $\mathrm{CO}_{2}$ monitor, and Harvard impactor PM sampling train, respectively. We thank priest of Gülbahçe Mosque, Mr. Alayittin Elsıkma for his cooperation and help. We also thank Prof.Dr. Thomas M. Holsen of Clarkson University, Potsdam, NY, USA and the two anonymus reviewers for valuable comments and suggestions.

\section{References}

Abt, E., Suh, H.H., Allen, G., Koutrakis, P., 2000a. Characterization of indoor particle sources: a study conducted in the metropolitan Boston area. Environmental Health Perspectives 108, 35-44.

Abt, E., Suh, H.H., Catalano, P., Koutrakis, P., 2000b. Relative contribution of outdoor and indoor particle sources to indoor concentrations. Environmental Science and Technology 34, 3579-3587.

Al-Ajmi, F.F., 2010. Thermal comfort in air-conditioned mosques in the dry desert climate. Building and Environment 45, 2407-2413.

Al-Homoud, M.S., Abdou, A.A., Budaiwi, I.M., 2009. Assessment of monitored energy use and thermal comfort conditions in mosques in hot-humid climates. Energy and Buildings 41, 607-614.

Alshitawi, M.S., Awbi, H.B., 2011. Measurement and prediction of the effect of students' activities on airborne particulate concentration in a classroom. HVAC\&R Research 17, 446-464.

Andersen, Z.J., Wahlin, P., Raaschou-Nielsen, O., Ketzel, M., Scheike, T., Loft, S., 2008. Size distribution and total number concentration of ultrafine and accumulation mode particles and hospital admissions in children and the elderly in Copenhagen, Denmark. Occupational and Environmental Medicine 65, 458-466.

ASHRAE, 2001. Standard 62-2001 Ventilation for Acceptable Indoor Air Quality. American Society of Heating, Refrigerating and Air-Conditioning Engineers, Atlanta, GA.

Branis, M., Safranek, J., Hytychova, A., 2009. Exposure of children to airborne particulate matter of different size fractions during indoor physical education at school. Building and Environment 44, 1246-1252.

Corsi, R.L., Siegel, J.A., Chiang, C., 2008. Particle resuspension during the use of vacuum cleaners on residential carpet. Journal of Occupational and Environmental Hygiene 5, 232-238.

Crist, K.C., Liu, B., Kim, M., Desphande, S.R., John, K., 2008. Characterization of fine particulate matter in Ohio: indoor, outdoor, and personal exposures. Environmental Research 106, 62-71.

de Kok, T.M.C.M., Hogervorst, J.G.F., Kleinjans, J.C.S., Briede, J.J., 2004. Radicals in the church. European Respiratory Journal 24, 1069-1070.

de Santis, F., Allegrini, I., Fazio, M.C., Pasella, D., 1996. Characterization of indoor air quality in the Church of San Luigi dei Francesi, Rome, Italy. International Journal of Environmental Analytical Chemistry 64, 71-81.

Durmus Arsan, Z., 2012. İzmir Institute of Technology. Building Physics Laboratory, İmir, Turkey.

Ekmekcioglu, D., Keskin, S.S., 2007. Characterization of indoor air particulate matter in selected elementary schools in Istanbul, Turkey. Indoor and Built Environment $16,169-176$

Fang, G.C., Chang, C.N., Wu, Y.S., Yang, C.J., Chang, S.C., Yang, I.L., 2002. Suspended particulate variations and mass size distributions of incense burning at Tzu Yun Yen temple in Taiwan, Taichung. Science of the Total Environment 299, 79-87.

Ferro, A.R., Kopperud, R.J., Hildemann, L.M., 2004. Source strengths for indoor human activities that resuspend particulate matter. Environmental Science and Technology 38, 1759-1764.

Fromme, H., Diemer, J., Dietrich, S., Cyrys, J., Heinrich, J., Lang, W., Kiranoglu, M., Twardella, D., 2008. Chemical and morphological properties of particulate matter (PM10, PM2.5) in school classrooms and outdoor air. Atmospheric Environment 42, 6597-6605.

Ghio, A.J., Kim, C., Devlin, R.B., 2000. Concentrated ambient air particles induce mild pulmonary inflammation in healthy human volunteers. American Journal of Respiratory and Critical Care Medicine 162, 981-988.

Hauser, R., Godleski, J.J., Hatch, V., Christiani, D.C., 2001. Ultrafine particles in human lung macrophages. Archives of Environmental Health 56, 150-156.

Health-Canada, 1987. Exposure Guidelines for Residential Indoor Air Quality. Health Canada, Environmental Health Directorate, Ottawa, Ontario.

Hinds, W.C., 1999. Aerosol Technology, second ed. John Wiley \& Sons, New York.

Long, C.M., Suh, H.H., Koutrakis, P., 2000. Characterization of indoor particle sources using continuous mass and size monitors. Journal of the Air and Waste Management Association 50, 1236-1250.

Loomis, D., 2000. Sizing up air pollution research. Epidemiology 11, 2-4.

Loupa, G., Karageorgos, E., Rapsomanikis, S., 2010. Potential effects of particulate matter from combustion during services on human health and on works of art in medieval churches in Cyprus. Environmental Pollution 158, 2946-2953.

Meng, Q.Y., Turpin, B.J., Korn, L., Weisel, C.P., Morandic, M., Colome, S., Zhang, J., Stock, T., Spektor, D., Winer, A., Zhang, L., Lee, J.H., Giovanetti, R., Cui, W. Kwon, J., Alimokhtari, S., Shendell, D., Jones, J., Farrar, C., Maberti, C., 2005. Influence of ambient (outdoor) sources on residential indoor and personal PM2.5 concentrations: analyses of RIOPA data. Journal of Exposure Analysis and Environmental Epidemiology 15, 17-28.

Parker, J.L., Larson, R.R., Eskelson, E., Wood, E.M., Veranth, J.M., 2008. Particle size distribution and composition in a mechanically ventilated school building during air pollution episodes. Indoor Air 18, 386-393.

Pekkanen, J., Timonen, K.L., Ruuskanen, J., Ruuskanen, J., Reponen, A., Mirme, A., 1997. Effects of ultrafine and fine particles in urban air on peak expiratory flow among children with asthmatic symptoms. Environmental Research 74, 24-33.

Pope, C.A., 2000. What do epidemiologic findings tell us about health effects of environmental aerosols? Journal of Aerosol Medicine 13, 335-354. 
Pope, C.A., Dockery, D.W., 2006. Health effects of fine particulate air pollution: lines that connect. Journal of the Air and Waste Management Association 56, 709-742.

Qian, J., Ferro, A.R., Fowler, K.R., 2008. Estimating the resuspension rate and residence time of indoor particles. Journal of the Air and Waste Management Association 58, 502-516.

Stranger, M., Potgieter-Vermaak, S.S., Van Grieken, R., 2008. Characterization of indoor air quality in primary schools in Antwerp, Belgium. Indoor Air 18, 454. Thatcher, T.L., Layton, D.W., 1995. Deposition, resuspension, and penetration of particles within a residence. Atmospheric Environment 29, 1487-1497.

Tippayawong, N., Khuntong, P., Nitatwichit, C., Khunatorn, Y., Tantakitti, C., 2009. Indoor/outdoor relationships of size-resolved particle concentrations in naturally ventilated school environments. Building and Environment 44 188-197.
USEPA, 2006. National Ambient Air Quality Standards for Particulate Matter. Final Rule, Federal Register. US Environmental Protection Agency.

Wang, B., Lee, S.C., Ho, K.F., Kang, Y.M., 2007. Characteristics of emissions of air pollutants from burning of incense in temples, Hong Kong. Science of the Total Environment 377, 52-60.

Ward, T.J., Noonan, C.K.H., 2007. Results of an indoor size fractionated PM school sampling program in Libby, Montana. Environmental Monitoring and Assessment $130,163-171$.

Weber, S., 2006. Exposure of churchgoers to airborne particles. Environmental Science and Technology 40, 5251-5256.

WHO, 2006. WHO Air Quality Guidelines for Particulate Matter, Ozone, Nitrogen Dioxide and Sulfur Dioxide. Global Update 2005. World Health Organization, Geneva, Switzerland. 